\title{
IMPACT OF EMOTIONAL MATURITY ON ADMINISTRATIVE LEADERSHIP OF COLLEGE PRINCIPLES
}

\author{
Mrs. Kamaljit Kaur \\ Assistant Professor \\ C.P.S.M College Of Education, \\ Gurgaon \\ EMAIL: kamal2nov@gmail.com
}

\begin{abstract}
The aim of the study was to find the Impact of Emotional maturity on the Administrative leadership of college principals. The data required for the study consisted of both primary and secondary data. Primary data pertained to Emotional maturity which was collected directly from the respondent. The secondary data covered the Administrative Skills of the principals of colleges of education which was collected from their teacher educators. Samples were collected from 100 colleges of education in Punjab. The investigator used the survey method as a main technique for investigation. The tool used for the study was Emotional Maturity Scale by Y.Singh and M.Bhargava and Administrative Skills Inventory validated by the investigator.
\end{abstract}

Key words: Administrative skills, emotional maturity, principals of colleges of education, survey method, random sampling technique.

\section{Introduction}

Educational administration is administration in the field of education. It is not possible in a vaccum. There is need of social environment for its running. The better the administration, the better becomes the social environment. In administration, we find that many human beings are involved i.e. administrator, teachers, students, ministerial 


\section{ELK ASIA PACIFIC JOURNAL OF SOCIAL SCIENCES}

ISSN 2394-9392 (Online); DOI: 10.16962/EAPJSS/issn.2394-9392/2014; Volume 2 Issue 1 (2015)

staff, employees, the public, the management, the controlling authorities at local, state and central level, all are affected by administration. A good administrator has his healthy effects on all concerned. The administrator with excellent administration is able to influence all concerned in an excellent way. According to the commission "Administration is essentially a matter of faith and vision, bold and courageous leadership, and proper handling of human relations. The importance of securing the right type of personnel for it cannot, therefore, be over emphasized. The major weaknesses of the existing organization of the state education departments are largely related to personnel. These include; shortage of personnel at higher level; lack of specialized staff; unsatisfactory remuneration and condition of service; unsatisfactory methods of recruitment; inadequate provision of in service education; and inadequate staffing", for the proper improvement, the commission suggested the creation of Indian Educational Service (IES), such a service would help the progress of education. The administration of an institution is the task of great responsibility that could only be handled by an emotionally mature person.

\section{Review of Related Literature}

Few studies related to some important aspects of administrative leadership and emotional maturity has been reviewed as under:

Linda, Rice. (1982) observes the characteristics and competencies needed by principals in schools serving special education students. Traits of empathy, integrity, honesty, creativity, and imagination are among those considered.

Fernandez, M.S. (1990) conducted "A study of the psychological aspects of human relations in educational administration of heads of schools". The study explores the influence of psychological factors like the headmasters' ego status, basic assumptions about the motivation for work on the part of teachers, the organizational climate and on the headmasters' sharing and shouldering of administrative responsibilities.

Dianne (1991) studied the effects of a statewide mentoring program for Illinois principals, with a focus on the reasons for principals' behavior changes. Methodology 


\section{ELK ASIA PACIFIC JOURNAL OF SOCIAL SCIENCES}

ISSN 2394-9392 (Online); DOI: 10.16962/EAPJSS/issn.2394-9392/2014; Volume 2 Issue 1 (2015)

involved interviews with six pairs of mentors and proteges, site observations, and artifact collection.

Condren, Tammy Dayle. (2002) studied the relationship between principal's emotional intelligence and leadership effectiveness. The objectives were to study the relationship between the emotional intelligence of the principal and teachers perception of the principals leadership effectiveness.

Zachariah, S .R. (2007) conducted a study on personality type and managerial performance- an enquiry into the nature of their relationships. The objectives of the study were :( 1) To assess the Performance level of Senior, Middle and Junior managers and to categorize them into high, medium and low performers.(2) To find out whether the performance of managers has any association with their personality types measured against the model of personality theorized by Myers and Briggs.(3) To assess the level of assertiveness possessed by the managers and to find out whether there is any relationship between managerial performance and level of assertiveness. (4) To find out the relationship, if any, between MBTl personality type of managers and their level of assertiveness. (5)
To find out whether performance differences among managers have any association with the socio-demographic background of managers such as education, age and upbringing.

K Jani,Gaganvihari (2015) conducted an investigation into the administrative patterns of the principals of secondary as well as higher secondary schools of Ahmedabad district. The main objectives of the study are i) To study and compare the administrative patterns of the principals of secondary as well as higher secondary schools of urban and rural areas of Ahmedabad District. ii) To study the correlation between the administrative effectiveness and personal variables like age, educational qualification and experience of the principal. iii) To study the correlation between the administrative effectiveness and institutional variables like area, type, school level, type of school management, number of staff members and Board Examination results of the school.

The review of related literature shows that there are some studies on the administrative skills of the administrators of educational institution. But in context to emotional maturity the number of studies in this area is 


\section{ELK ASIA PACIFIC JOURNAL OF SOCIAL SCIENCES}

ISSN 2394-9392 (Online); DOI: 10.16962/EAPJSS/issn.2394-9392/2014; Volume 2 Issue 1 (2015)

very rare. Thus, the investigator felt the need to fill this gap to a certain extent.

\section{Objectives of the Study}

The present study has been undertaken to know the impact of emotional maturity on the administrative leadership of college principals with the following objectives:

i. To assess the emotional maturity of the principals of colleges of education.

ii. To assess the administrative skills of the principals of colleges of education.

iii. To assess the impact of emotional maturity of the principals of colleges of education on their administrative skills.

\section{Methodology and Procedure}

For the present investigation the researcher used survey method for collecting the relevant data. The investigator followed random sampling technique. The sample consisted of two categories viz. a) Principals of Colleges of Education b) Teacher Educators of Colleges of Education. Samples were collected from 100 colleges of education in Punjab. The tools used for the study are the Emotional Maturity Scale by Y.Singh and M.Bhargava and Administrative Skills Inventory validated by the investigator. The data obtained was analyzed using basic descriptive statistics such as Mean, Median, Standard Deviation and Skewness. The other statistics used for analyzing the data are Pearson correlation coefficient, Lambda correlation coefficient, Cross tabulation, First order partial correlation, Regression analysis, two-tailed and one-tailed test of significance, f-test for significance value and Normal probability distribution.

\section{Findings}

i. To assess the emotional maturity of the principals of colleges of education.

The table 1.1 shows that for the variable emotional maturity the standard deviation obtained is 0.750 , which is quite high (>0.7). High standard deviation indicates that the data points are spread out over a large range of values. Hence, there is significant difference in the emotional maturity of the principals of colleges of education in Punjab.

(Refer Table 1.1 Here)

(Refer Table 1.2 Here) 


\section{ELK ASIA PACIFIC JOURNAL OF SOCIAL SCIENCES}

ISSN 2394-9392 (Online); DOI: 10.16962/EAPJSS/issn.2394-9392/2014; Volume 2 Issue 1 (2015)

Table 1.2 lists the values of the variable emotional maturity (Extremely, moderately, immature, extremely immature) of the principals of colleges of education in Punjab and the frequency of occurrence of each.

\section{(Refer Figure 1.1 Here)}

The bar chart in figure 1.1 shows that $44 \%$ of principals of colleges of education in Punjab are extremely mature, $40 \%$ are moderately mature, $15 \%$ are immature and only $1 \%$ of principals are extremely immature. Hence, there is significant difference in the emotional maturity of the principals of colleges of education in Punjab.

ii. To assess the administrative skills of the principals of colleges of education.

The table 2.1 describing the central tendency, dispersion and distribution for administrative skills shows that the standard deviation obtained is 0.716 , which is quite high $(>0.7)$. High standard deviation indicates that the data points are spread out over a large range of values. Hence, there is significant difference in the administrative skills of the principals of colleges of education in Punjab.

(Refer Table 2.1 Here)
(Refer Table 2.2 Here)

The table 2.2 lists the values of the variable administrative skills (Average, Good and Excellent) of the principals of colleges of education in Punjab and the frequency of occurrence of each

(Refer Figure 2.1 Here)

The above Pie- Chart in figure 2.1 shows $49 \%$ of principals of colleges of education in Punjab are having excellent administrative skills, $37 \%$ are having good administrative skills and only $14 \%$ of principals of colleges of education in Punjab are having average administrative skills. Hence, there is significant difference in the administrative skills of the principals of colleges of education in Punjab.

iii. To assess the impact of emotional maturity of the principals of colleges of education on their administrative skills.

\section{(Refer Table 3.1 Here)}

In the Table 3.1 each subscript letter denotes a subset of Emotional Maturity categories whose column proportions do not differ significantly from each other at the .05 level. 


\section{ELK ASIA PACIFIC JOURNAL OF SOCIAL SCIENCES}

ISSN 2394-9392 (Online); DOI: 10.16962/EAPJSS/issn.2394-9392/2014; Volume 2 Issue 1 (2015)

From above table, we can say that 40 principals of colleges of education are extremely mature with excellent administrative skills and no principal of college of education is extremely mature with average administrative skills. Only one principal of college of education was found extremely immature with excellent administrative skills. Thirty principals of colleges of education are moderately mature with good administrative skills.

The table 3.2 showing directional measures quantify the reduction in the error of predicting the row variable value when we know the column variable value, or vice versa shows that the zero significant value is obtained by performing Pearson's Test and value for Lambda is $>0.6$ which shows that there is significant impact of emotional maturity of the principals of colleges of education on their administrative skills.

(Refer Table 3.2 Here)

Table 3.2: Directional measures quantify the reduction in the error of predicting the row variable value when we know the column variable value, or vice versa.

The bar graph in figure 3.1 shows that no principal of colleges of education in Punjab is extremely mature if they are having average administrative skills, whereas more than 40 principals of colleges of education are extremely mature if they are having average administrative skills. Similarly, nearly 30 principals of colleges of education are moderately mature if they are having good administrative skills. The number of immature principals of colleges of education decreases gradually as their administrative skills improves.

(Refer Figure 3.1 Here)

\section{Conclusion}

i. $44 \%$ of principals of colleges of education in Punjab are extremely mature, $40 \%$ are moderately mature, $15 \%$ are immature and only $1 \%$ of principals of colleges of education are extremely immature. Hence, there is significant difference in the emotional maturity of the principals of colleges of education in Punjab.

ii. $49 \%$ of principals of colleges of education in Punjab are having excellent administrative skills, 37\% are having good administrative skills and only $14 \%$ of principals of colleges of education in Punjab are having average administrative skills. Hence, there is significant difference in the administrative skills of the principals of colleges of education in Punjab. 


\section{ELK ASIA PACIFIC JOURNAL OF SOCIAL SCIENCES}

ISSN 2394-9392 (Online); DOI: 10.16962/EAPJSS/issn.2394-9392/2014; Volume 2 Issue 1 (2015)

iii. 40 principals of colleges of education are extremely mature with excellent administrative skills and no principal of colleges of education is extremely mature with average administrative skills. Only one principal of college of education was found extremely immature with excellent administrative skills. Thirty principals of colleges of education are moderately mature with good administrative skills. No principal of colleges of education in Punjab is extremely mature if they are having average administrative skills, whereas more than 40 principals of colleges of education are extremely mature if they are having average administrative skills. Similarly, nearly 30 principals of colleges of education are moderately mature if they are having good administrative skills. The number of immature principals of colleges of education decreases gradually as their administrative skills improves

Suggestions for the further research:
1. This study is conducted in Punjab state only. Other parts of our country can be selected for the study.

2. Administrative skills of principals of arts and science colleges and professional colleges- A comparative analysis in terms of perception of their subordinates.

3. Administrative behaviour among the principals of colleges of education in relation to the organizational climate of the institution may be studied.

\section{References}

Books

Bala, M. (1990). Leadership Behavior in Educational Administration. Deep and Deep Publishers, New Delhi

Bhatt, B. D. and Sharma, S.R. (1992). Educational Administration. Kanishka, New Delhi.

Ebel, L \& Frisbie, A. (1991). Essentials of Educational Measurement. Prentice Hall, USA.

Kuppuswamy, B. (1993). An Introduction to Social Psychology. Media Publishers 


\section{ELK ASIA PACIFIC JOURNAL OF SOCIAL SCIENCES}

ISSN 2394-9392 (Online); DOI: 10.16962/EAPJSS/issn.2394-9392/2014; Volume 2 Issue 1 (2015)

and Promoters Pvt. Ltd., Bombay - 400 007.

Schermerhorn, J.R. (1996). Management and Organizational Behaviour Essential.

John Wiley and Sans, Inc., New Jersey.

Thrupp,Martin.(2003). Educational

Management in Managerialist Times-

Beyond the Textual Apologist. McGraw-

Hill Education

\section{JOURNALS}

Bennis, W. G. (1959). Leadership Theory and Administrative Behavior: The Problem of Authority. Administrative Science Quarterly, 4, 259-260.

Hop, A.F. (1999). Power in the Principalship: Four Women's Experiences. Journal of Educational Administration, 37, 23-49.

Robert, S.E. (1974). Educational Management and Information. Journal of Educational Data Processing, 11, 1-10.

\section{List Of Figures:}

Figure 1.1: Bar-chart showing the count for each distinct value for emotional maturity variable 


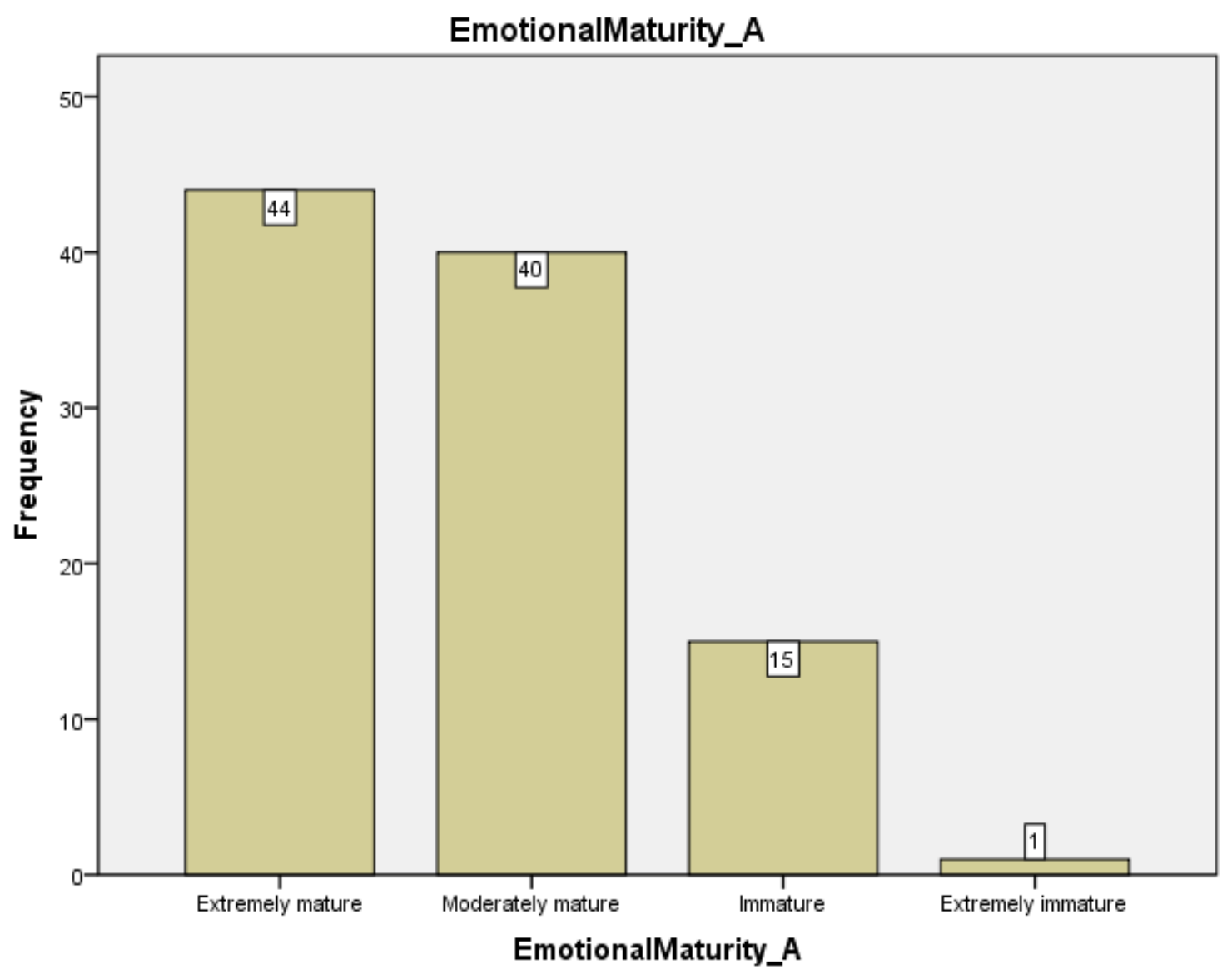

Figure 2.1: Pie-chart showing the count for each distinct value for administrative skills variable 

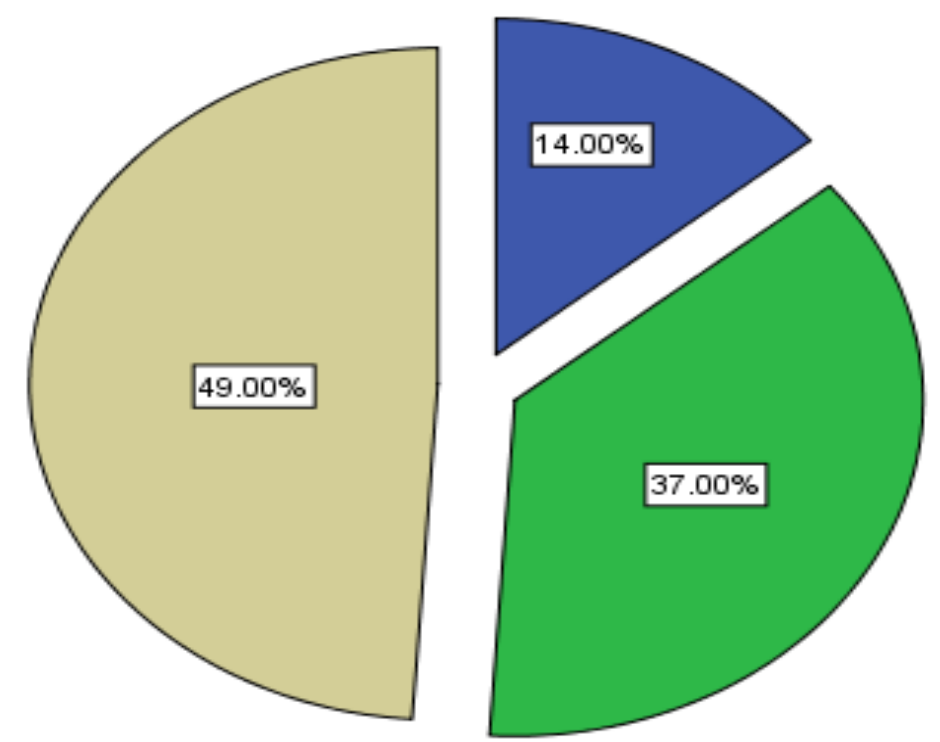

Figure 3.1: Bar graph between emotional maturity and administrative skills 


\section{ELK ASIA PACIFIC JOURNAL OF SOCIAL SCIENCES}

ISSN 2394-9392 (Online); DOI: 10.16962/EAPJSS/issn.2394-9392/2014; Volume 2 Issue 1 (2015)

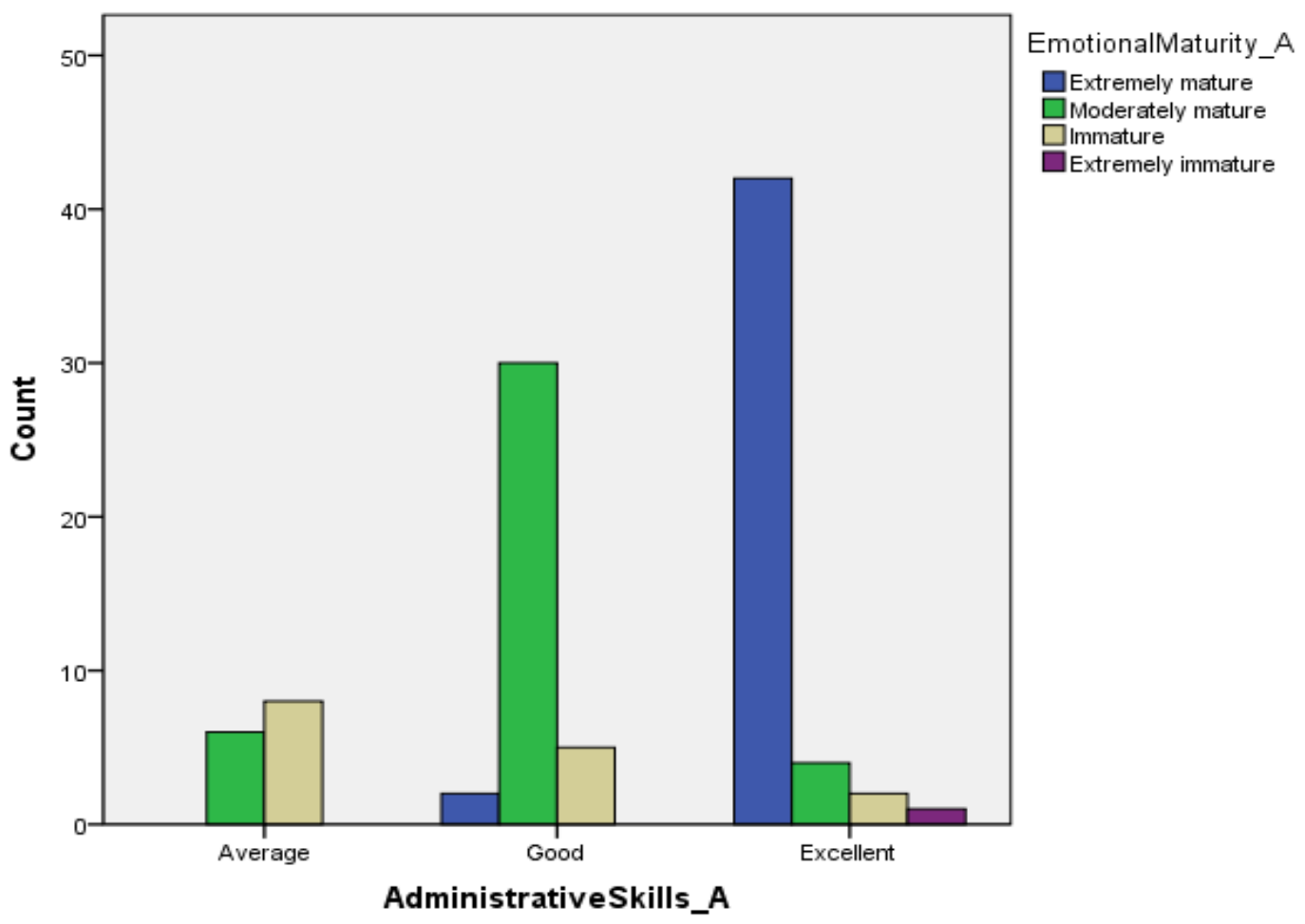

\section{List of Tables:}


Table 1.1: Describing the central tendency, dispersion and distribution for emotional maturity variable ( $\mathrm{N}=100$ cases).

\begin{tabular}{|c|c|c|}
\hline \multirow[t]{2}{*}{$\mathrm{N}$} & Valid & 100 \\
\hline & Missing & 0 \\
\hline \multicolumn{2}{|c|}{ Mean } & 1.73 \\
\hline \multicolumn{2}{|c|}{ Median } & 2.00 \\
\hline \multicolumn{2}{|c|}{ Std. Deviation } & .750 \\
\hline \multicolumn{2}{|c|}{ Skewness } & .637 \\
\hline \multicolumn{2}{|c|}{ Std. Error of Skewness } & .241 \\
\hline
\end{tabular}

Table 1.2: Frequency distribution of all values from emotional maturity variable 


\begin{tabular}{|l|r|r|r|r|}
\hline & Frequency & Percent & $\begin{array}{l}\text { Valid } \\
\text { Percent }\end{array}$ & \multicolumn{2}{l|}{$\begin{array}{l}\text { Cumulative } \\
\text { Percent }\end{array}$} \\
\hline $\begin{array}{l}\text { Valid Extremely } \\
\text { mature }\end{array}$ & 44 & 44.0 & 44.0 & 44.0 \\
$\begin{array}{l}\text { Moderately } \\
\text { mature }\end{array}$ & 40 & 40.0 & 40.0 & 84.0 \\
$\begin{array}{l}\text { Immature } \\
\text { Extremely } \\
\text { immature }\end{array}$ & 15 & 15.0 & 15.0 & 99.0 \\
Total & 100 & 100.0 & 1.0 & 100.0 \\
\hline
\end{tabular}

Table 2.1: Describing the central tendency, dispersion and distribution for administrative skills variable ( $\mathrm{N}=100$ cases $)$.

\begin{tabular}{|c|c|c|}
\hline $\mathrm{N}$ & $\begin{array}{l}\text { Valid } \\
\text { Missing }\end{array}$ & 100 \\
\hline \multicolumn{2}{|c|}{ Mean } & 3.35 \\
\hline \multicolumn{2}{|c|}{ Median } & 3.00 \\
\hline \multicolumn{2}{|c|}{ Std. Deviation } & .716 \\
\hline \multicolumn{2}{|c|}{ Skewness } & -.634 \\
\hline \multicolumn{2}{|c|}{ Std. Error of Skewness } & .241 \\
\hline
\end{tabular}

Table 2.2: Frequency distribution of all values from administrative skills variable 


\begin{tabular}{|c|r|r|r|r|}
\hline & Frequency & Percent & $\begin{array}{l}\text { Valid } \\
\text { Percent }\end{array}$ & \multicolumn{2}{l|}{$\begin{array}{l}\text { Cumulative } \\
\text { Percent }\end{array}$} \\
\hline Valid Average & 14 & 14.0 & 14.0 & 14.0 \\
Good & 37 & 37.0 & 37.0 & 51.0 \\
Excellent & 49 & 49.0 & 49.0 & 100.0 \\
Total & 100 & 100.0 & 100.0 & \\
\hline
\end{tabular}

Table 3.1: The cross-tabulation showing the frequency of each emotional maturity with respect to the administrative skills of principals

\begin{tabular}{|ll|r|r|r|r|r|}
\hline & & \multicolumn{3}{|l|}{ EmotionalMaturity_A } & \\
\cline { 2 - 6 } & & $\begin{array}{l}\text { Extremely } \\
\text { mature }\end{array}$ & $\begin{array}{l}\text { Moderately } \\
\text { mature }\end{array}$ & Immature & $\begin{array}{l}\text { Extremely } \\
\text { immature }\end{array}$ & Total \\
\hline Administrative & Average & 0 & 6 & $8 \mathrm{c}$ & $0_{\mathrm{a}, \mathrm{b}, \mathrm{c}}$ & 14 \\
Skills_A & Good & $2 \mathrm{a}$ & $30_{\mathrm{b}}$ & $5_{\mathrm{c}}$ & $0_{\mathrm{a}, \mathrm{b}, \mathrm{c}}$ & 37 \\
& Excellent & $42_{\mathrm{a}}$ & $4 \mathrm{~b}$ & $2 \mathrm{~b}$ & $1_{\mathrm{a}}$ & 49 \\
& & 44 & 40 & 15 & 1 & 100 \\
\hline
\end{tabular}

Table 3.2: Directional measures quantify the reduction in the error of predicting the row variable value when we know the column variable value, or vice versa. 


\begin{tabular}{|c|c|c|c|c|c|c|}
\hline & & & Value & $\begin{array}{l}\text { Asymp. } \\
\text { Std. } \\
\text { Error }^{\mathrm{a}}\end{array}$ & $\begin{array}{l}\text { Appro } \\
x . T^{b}\end{array}$ & $\begin{array}{l}\text { Approx } \\
\text { Sig. }\end{array}$ \\
\hline \multirow{5}{*}{$\begin{array}{l}\text { Nominal by } \\
\text { Nominal }\end{array}$} & \multirow{3}{*}{ Lambda } & Symmetric & .636 & .072 & 6.375 & .000 \\
\hline & & $\begin{array}{l}\text { Administrative } \\
\text { Skills_A } \\
\text { Dependent }\end{array}$ & .627 & .079 & 5.507 & .000 \\
\hline & & $\begin{array}{l}\text { Emotional } \\
\text { Maturity_A } \\
\text { Dependent }\end{array}$ & .643 & .067 & 6.923 & .000 \\
\hline & \multirow[t]{2}{*}{$\begin{array}{l}\text { Goodman and } \\
\text { Kruskal tau }\end{array}$} & $\begin{array}{l}\text { Administrative } \\
\text { Skills_A } \\
\text { Dependent }\end{array}$ & .522 & .071 & & $.000^{\mathrm{c}}$ \\
\hline & & $\begin{array}{l}\text { Emotional } \\
\text { Maturity_A } \\
\text { Dependent }\end{array}$ & .498 & .075 & & $.000^{c}$ \\
\hline
\end{tabular}

